\title{
Sediment core fossils in ancient Lake Ohrid: testing for faunal change since the Last Interglacial
}

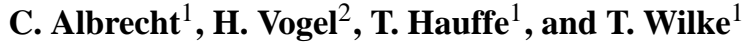 \\ ${ }^{1}$ Department of Animal Ecology \& Systematics, Justus Liebig University Giessen, Germany \\ ${ }^{2}$ Institute of Geology and Mineralogy, University of Cologne, Germany
}

Received: 5 May 2010 - Published in Biogeosciences Discuss.: 28 May 2010

Revised: 8 October 2010 - Accepted: 11 October 2010 - Published: 5 November 2010

\begin{abstract}
Ancient Lake Ohrid is probably of early Pleistocene or Pliocene origin and amongst the few lakes in the world harbouring an outstanding degree of endemic biodiversity. Although there is a long history of evolutionary research in Lake Ohrid, particularly on molluscs, a mollusc fossil record has been missing up to date.

For the first time, gastropod and bivalve fossils are reported from the basal, calcareous part of a $2.6 \mathrm{~m}$ long sediment succession (core Co1200) from the north-eastern part of Lake Ohrid. Electron spin resonance (ESR) dating of mollusc shells from the same stratigraphic level yielded an age of $130 \pm 28 \mathrm{ka}$. Lithofacies III sediments, i.e. a stratigraphic subdivision comprising the basal succession of core Co1200 between $181.5-263 \mathrm{~cm}$, appeared solid, greyish-white, and consisted almost entirely of silt-sized endogenic calcite $\left(\mathrm{CaCO}_{3}>70 \%\right)$ and intact and broken mollusc shells. Here we compare the faunal composition of the thanatocoenosis with recent mollusc associations in Lake Ohrid. A total of 13 mollusc species (9 gastropod and 4 bivalve species) could be identified within Lithofacies III sediments. The value of sediment core fossils for reconstructing palaeoenvironmental settings was evaluated and the agreement between sediment and palaeontological proxies was tested.

The study also aims at investigating major faunal changes since the Last Interglacial and searching for signs of extinction events.

The combined findings of the ecological study and the sediment characteristics suggest deposition in a shallow water environment during the Last Interglacial. The fossil fauna exclusively included species also found in the present fauna, i.e. no extinction events are evident for this site since the Last Interglacial. The thanatocoenosis showed the highest similarity with recent Intermediate Layer (5-25 m water depth)
\end{abstract}

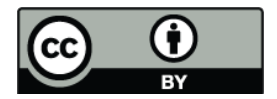

Correspondence to: C. Albrecht (christian.albrecht@allzool.bio.uni-giessen.de) mollusc assemblages. The demonstrated existence of a mollusc fossil record in Lake Ohrid sediment cores also has great significance for future deep drilling projects. It can be hoped that a more far reaching mollusc fossil record will then be obtained, enabling insight into the early evolutionary history of Lake Ohrid.

\section{Introduction}

Ancient lakes, that is, extant lakes that have continuously existed for a hundred thousand or even for millions of years, are well recognized as hotspots of freshwater biodiversity (e.g. Martens, 1997). The few worldwide ancient lakes also provide invaluable archives of tectonic (Müller et al., 2001), climate (Scholz et al., 2007), environmental (Wagner et al., 2009), and evolutionary histories (Schwarzer et al., 2009), spanning time frames from the Miocene to the Holocene. Though most current research focuses on extant taxa, palaeontological research in ancient lakes has a long and rich history, and important evolutionary concepts such as the theory of the punctuated equilibrium (e.g. Williamson, 1981; but see van Boxclaer et al., 2008) are derived from ancient lake research. The question of long-term stability vs. rapid changes as ultimate cause for diversification events is among the most intensively discussed issues in ancient lake research (e.g. van Boxclaer et al., 2008). Among fossilized taxa, the molluscs often figure prominently in many lake sediments, thus reflecting a long and diverse evolutionary history because of their excellent preservation potential (e.g. Taylor, 1988; Tracey et al., 1993; Wesselingh, 2007). Fossilized molluscs have a number of advantages over other taxa: (i) determination is typically possible down to the genus or even species level, (ii) they frequently belong to the most conspicuous fossils, (iii) though lacustrine fossil assemblages may vary in quality mainly depending on abiotic factors such as water chemistry (van Damme and

Published by Copernicus Publications on behalf of the European Geosciences Union. 
Pickford, 2003), they may occur as preserved shells, molds, or casts. Therefore, they are often used as valuable indicators of palaeoecological conditions such as water temperature (Goodwin et al., 2003), lake-level fluctuations (Filipov and Riedel, 2009), depth information and oxygen conditions (Magyar et al., 2006), salinity (e.g. Mischke et al., 2010), and primary productivity (Langlet et al., 2007). They also serve as important proxis for environmental changes (e.g. Harzhauser and Mandic, 2008).

For example, a number of Neogene palaeolakes exist on the Balkans that are characterized by a high degree of mollusc diversity and endemism (Harzhauser et al., 2008). These lakes are excellent archives of past climate changes with records mirroring even decadal to centennial shifts of the respective palaeolimnological system (Harzhauser et al., 2008; Lirer et al., 2009). The excellent fossil records of those lakes provided insights into, for example, the geological evolution of the eastern Mediterranean (e.g. Rust, 1997), climate and environmental change (Owen et al., 2010), patterns and processes of radiations, and biogeographical patterns (Harzhauser and Mandic, 2010). There is a well-known modern counterpart to those long-lived Neogene lakes, the ancient Lake Ohrid (Macedonia, Albania; Fig. 1). This lake has been in the focus of evolutionary biologists for more than 100 years because of its outstanding biodiversity and degree of endemism (reviewed in Albrecht and Wilke, 2008). Over the past years, our knowledge of evolutionary histories of important recent taxa has increased rapidly (Albrecht et al., 2006, 2008; Hauffe et al., 2010; Hauswald et al., 2008; Schultheiß et al., 2008; Wysocka et al., 2008; Trajanovski et al., 2010; Wilke et al., 2010). Although probably of early Pleistocene or Pliocene origin, the exact age and origin of Lake Ohrid remain unknown, though a number of hypotheses as to its geological and limnological history have been proposed (reviewed in Albrecht and Wilke, 2008). Major progress has recently been made with respect to modern limnological and hydrological studies (Matzinger et al., 2006a, 2007; Vogel et al., 2010a), as well as palaeolimnological studies in the lake (Wagner et al., 2009). New insights are now available into environmental dynamics and their impact on sedimentation in Lake Ohrid over the last glacial-interglacial cycle (Vogel et al., 2010b) and on changes of the hydrological budget of the lake (Leng et al., 2010; Lindhorst et al., 2010). Stratigraphic and chronological precision has been enhanced by radiocarbon, luminescence, and electron spin resonance dating, and in particular tephrostratigraphy (Vogel et al., 2010c; Lindhorst et al., 2010; Sulpizio et al., 2010).

Although fossil diatom and ostracod records have been studied using sediment successions from the pelagic parts of Lake Ohrid (Wagner et al., 2009; Belmecheri et al., 2009) a similar study for the littoral parts is missing to date. Littoral parts of the lake are particularly interesting for studies of their mollusc faunal assemblages, as they not only harbour a high degree of endemic representatives (e.g. Hauffe et al., 2010), but also because these shallow parts are particularly

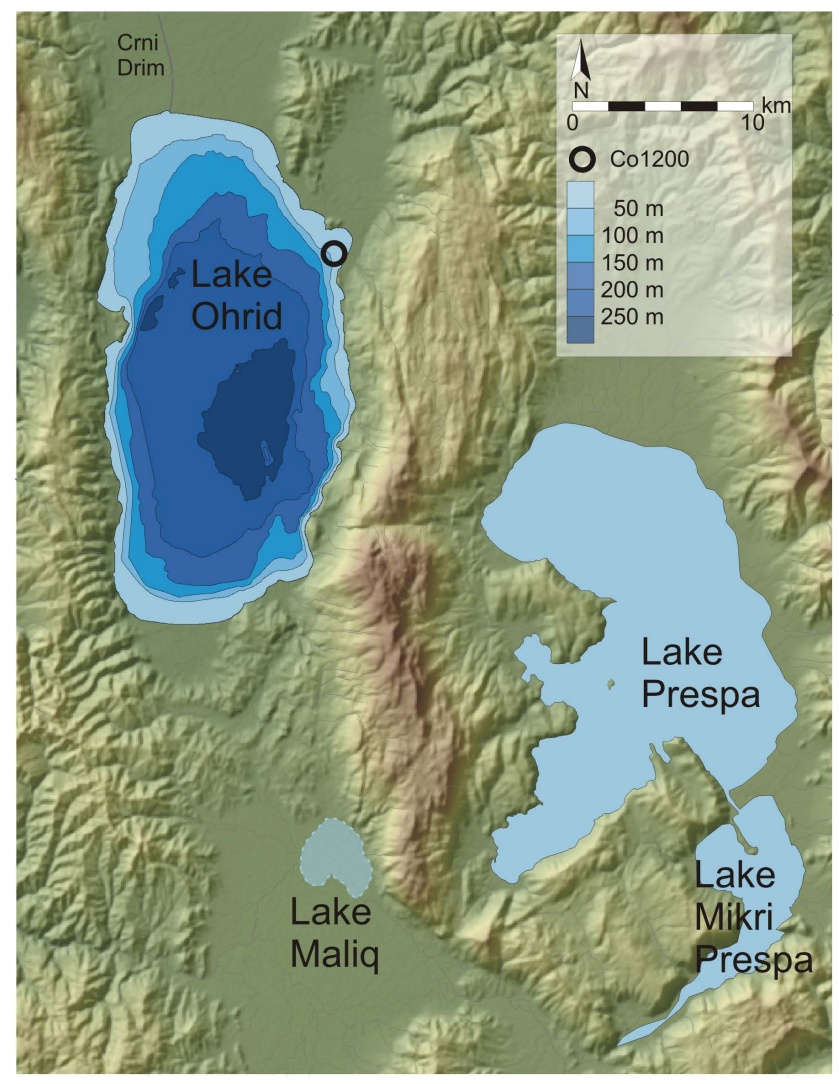

Fig. 1. Location of lakes Ohrid and Prespa and former Lake Maliq in the Macedonian-Albanian-Greek border zone. Shape and topographic setting of Lake Ohrid, bathymetry of Lake Ohrid in $50 \mathrm{~m}$ contour intervals with the location of coring site Co1200. Note that only the approximate location of former Lake Maliq is shown.

vulnerable to environmental changes (Vogel et al., 2010a; Kostoski et al., 2010). The lack of mollusc fossils, however, has been a very unfortunate situation given the rich fossil mollusc assemblages of Neogene (Harzhauser et al., 2008) and Pleistocene lakes (Frogley et al., 2007) on the Balkans and thus the potential for supraregional comparisons.

Numerous long sediment records of up to $15 \mathrm{~m}$ length have been recovered from hemi-pelagic sites in Lake Ohrid (Roelofs and Kilham, 1983; Wagner et al., 2008a, b; 2009; Belmecheri et al., 2009; Vogel et al., 2010b, c). However, sediment records from shallower littoral parts have only recently become available (Lindhorst et al., 2010). Combined hydroacoustic and lithological data from these shallow water sites revealed significant lake level fluctuations, which led to the formation of widespread terrace levels below the present water level during marine isotope stages (MIS) 6 and 5 (Lindhorst et al., 2010).

Here we report on the first record of gastropod and bivalve fossils discovered in the basal, calcareous part of a $2.6 \mathrm{~m}$ long sediment succession (core Co1200) from the north-eastern part of Lake Ohrid (Fig. 1). Electron spin resonance (ESR) 
dating of mollusc shells from the same stratigraphic level was used for chronological constraints. We here utilize statistical faunal comparisons of the thanatocoenosis with modern mollusc associations in Lake Ohrid in order to:

i. evaluate the value of sediment core fossils for reconstructing palaeoenvironmental settings,

ii. test for agreement between sediment and palaeontological proxies,

iii. test for major faunal changes since the Last Interglacial,

iv. search for signs of extinction events.

\section{Materials and methods}

\subsection{Site description}

Lake Ohrid (Ohridsko Ezero (Macedonian), Liqeni i Ohrit (Albanian)) is part of the European lake group called Dessaretes, located on the Balkan Peninsula (Fig. 1). The most outstanding of them is the oligotrophic and karstic Lake Ohrid, a steep-sided tectonically active graben situated in the South Adriatic-Ionian biogeographic region (Banarescu, 1991). The lake has a surface area of $358 \mathrm{~km}^{2}$ and a maximum depth of $289 \mathrm{~m}$ (Matzinger et al., 2007).

Lake Ohrid is an oligomictic lake with complete mixing occurring roughly every seven to ten years (Hadzisce, 1966 in Matzinger et al., 2006a, b). Secchi disk transparency varied between 9 and $17 \mathrm{~m}$ in the year 2005 (Naumoski et al., 2007). The water balance of the lake shows average inand output rates of approximately $37.9 \mathrm{~m}^{3} \mathrm{~s}^{-1}$ (Matzinger et al., 2006b). Today's water input of Lake Ohrid is characterized by inflows from karstic aquifers $(\sim 53 \%)$, direct precipitation on the lake surface $(\sim 23 \%)$, and river inflow $(\sim 23 \%)$. The river discharge was even lower before the River Sateska was artificially diverted into the lake in 1962 (Matzinger et al., 2006a). A specific characteristic of Lake Ohrid's water balance is the high inflow from karstic springs with sublacustrine $(49 \%)$ and surface springs $(51 \%)$ contributing almost equally to the inflow balance (Matzinger et al., 2006a). The output occurs via the River Crni Drim $(2 / 3)$ and through evaporation (1/3). The catchment area of Lake Ohrid is relatively small with $2600 \mathrm{~km}^{2}$ (including Lake Prespa; Matzinger et al., 2007). Though, Lake Ohrid can still be classified as oligotrophic, progressing eutrophication has recently been noted (Matzinger et al., 2007).

\subsection{Core recovery}

Sediment core Co1200 was recovered in autumn 2007 from the north-eastern part of Lake Ohrid (Fig. 1) where hydroacoustic surveys indicated a sub-aquatic terrace at a water depth of $32 \mathrm{~m}$ (Lindhorst et al., 2010). The surface sediments and deeper sediments were collected using a $0.6 \mathrm{~m}$ long gravity corer and a $3 \mathrm{~m}$ long percussion piston corer, respectively (both UWITEC Co.). The $3 \mathrm{~m}$ long core segments were subdivided into $1 \mathrm{~m}$ long segments in the field.

\subsection{Sediment analysis}

After longitudinal splitting of the cores, one core half was used for high-resolution X-ray fluorescence (XRF) scanning using an ITRAX core scanner (COX Ltd.), equipped with a Mo-tube set to $30 \mathrm{kV}$ and $30 \mathrm{~mA}$ and a Si-drift chamber detector. Scanning was performed at $2.5 \mathrm{~mm}$ resolution and an analysis time of $20 \mathrm{~s}$ per measurement. The obtained count rates for $\mathrm{Ti}, \mathrm{K}$, and $\mathrm{Ca}$ can be used as estimates of the relative concentrations for these elements (Croudace et al., 2006).

Sub-sampling was performed on the same core half used for XRF-scanning at $2 \mathrm{~cm}$ intervals. The water content (WC) for each sample was determined from the weight difference between wet and freeze-dried samples. Aliquots of the freeze-dried subsamples were ground to $<63 \mu \mathrm{m}$ using a planetary mill for subsequent biogeochemical analyses, which was done at $6 \mathrm{~cm}$ resolution. Total carbon (TC) concentrations, were measured with a Vario Micro Cube combustion CNS elemental analyzer (VARIO Co). Samples for total organic carbon (TOC) analysis were pre-treated with $\mathrm{HCl}(10 \%)$ at a temperature of $80^{\circ} \mathrm{C}$ to remove carbonates and then analyzed using a Leco CS-225 carbon-sulfur detector (LECO Co). The amount of total inorganic carbon (TIC) was determined from the difference between TC and TOC. The carbonate $\left(\mathrm{CaCO}_{3}\right)$ content was calculated from TIC under the assumption that TIC solely originates from $\mathrm{CaCO}_{3}$.

\subsection{Dating}

In order to develop a chronological framework for core Co1200, radiocarbon, electron spin resonance (ESR) dating, and tephrostratigraphy were applied. Radiocarbon dating was performed on plant macrofossils from 6 and $13 \mathrm{~cm}$ depth in core Co1200 by accelerator mass spectrometry (AMS) at the Leibniz Laboratory for Radiometric Dating and Isotope Research in Kiel, Germany. The obtained ages were calibrated into calendar years before the present (cal yrs BP) using the CalPal-2007 online and the CalPal2007_HULU calibration curve (Danzeglocke et al., 2008).

ESR dating was performed on mollusc shells extracted from a horizon containing large quantities of well-preserved fossil mollusc specimens at a depth of 230-262 cm. ICPmass spectrometry was applied in order to determine the radionuclide contents of the surrounding sediment and of the molluscs themselves. The ESR measurements were carried out using an additive dose protocol for multiple aliquots (Schellmann et al., 2008).

Core Co1200 contained two peculiar horizons at $40-38 \mathrm{~cm}$ and $85.5-120.5 \mathrm{~cm}$, which consisted almost entirely of volcanic glass shards (tephra). From these horizons about 
$1 \mathrm{~cm}^{3}$ was washed and sieved. The $>40 \mu \mathrm{m}$ fraction was embedded in epoxy resin and screened for glass shards and micro-pumice fragments using scanning electron microscopy (SEM). Energy-dispersive-spectrometry (EDS) analyses of glass shards and micro-pumice fragments was performed using an EDAX-DX micro-analyser mounted on a Philips SEM 515 (operating conditions: $20 \mathrm{kV}$ acceleration voltage, $100 \mathrm{~s}$ live time counting, 200-500 $\mathrm{nm}$ beam diameter, 2, 100-2, 400 shots per second, ZAF correction).

\subsection{Sampling mollusc fauna}

Materials on recent molluscs from the Ohrid Basin, including ponds, springs, artificial lakes, streams and rivers were collected during several field trips carried out between May 2003 and September 2009 (see Hauffe et al., 2010). Individuals were collected by hand from hard substrata in shallow waters or from stones and rocks lifted from depths down to $5 \mathrm{~m}$ by snorkeling. Deeper parts down to $60 \mathrm{~m}$ were sampled using a dredge from small boats or from the research vessel of the Hydrobiological Institute in Ohrid (HBI). Locality information (georeferenced with Garmin handheld GPS devices) and collection details were recorded for a total of 156 sampling points. All materials are deposited at the permanent DNA, shell and tissue collection of the University of Giessen, Systematics and Biodiversity Group (UGSB).

The abundance of the fossil species was estimated by counting recognizable complete or near complete shells. Species that were represented by less than 5 specimens were regarded as rare, 5 to 50 specimens as common, and more than 50 specimens as frequent. Bivalve valves were counted as halves. The classification scheme of the species is described in Hauffe et al. (2010).

\subsection{Analyses of faunal similarity and ecology statistics}

A comparative analysis of the Co1200 thanatocoenosis and recent gastropod assemblages was carried out to identify the recent depth range of the assemblage with the highest similarity to the thanatocoenosis. Bray-Curtis dissimilarities were calculated for pairwise comparisons of the fossil assemblages with the 156 recent gastropod assemblages (Hauffe et al., 2010), utilizing the $R$ package vegan 1.18 (Oksanen et al., 2010). These distances were calculated for three different habitats (depth zones) according to Albrecht and Wilke (2008) and Hauffe et al. (2010). 81 points were included for the shallow sandy or rocky Surface Layer (0$5 \mathrm{~m}), 41$ for the Intermediate Layer (5-25 m), characterized by the Chara belt and Dreissena beds, and 34 for the sandy and silty Deep Layer (25-50 m). Due to the unequal group size and non-normal distribution of the dissimilarities, a nonparametric analysis of variance (PERMANOVA, Anderson, 2001) was carried out with the function adonis of the vegan package. Given that the thanatocoenosis was used for multiple comparisons, which leads to an increase of the degrees of freedom, a Bonferroni adjustment for the Type I error inflation was carried out.

A non-metric multidimensional scaling (NMDS) was performed because of its robustness as compared to other ordination methods. In order to estimate a possibly depth range, we apply a posteriori vector fitting to the ordination result. The vector fitting algorithm of the $R$ package vegan is able to handle the unknown depth information, thus, can provide an estimation of the depth range and depth layer of the fossil gastropod assemblage.

Quartile box plots of the recent depth range of the nine gastropod and three bivalve species present in Co1200 were calculated to compare the inferred habitat with recent bathymetric preferences of the individual species. This allows cross-checking for consistency of the results of the potential habitat analyses. Pisidium subtruncatum was excluded from this comparison due to its rare recent records. Unequal numbers of recent collecting points in the different depth layers were balanced by sampling without replacement. The lowest number of collecting points (Deep Layer, $\mathrm{N}=34$ ) was utilized to sample 1000 times a set of 34 random collecting points of each of the different depth layers. Our procedure tested whether the particular species was found at those random points. If one species was not found at one of those points, this record was excluded from the subsequent analysis. Otherwise, the depth information of the collecting point was used to calculate the box plots of the depth distributions of the species.

For horizontal and vertical comparison of the thanatocoenosis of core Co1200 and recent gastropod communities in ancient Lake Ohrid, a dissimilarity map was obtained by the $R$ package spatstat 1.17-5 (Baddeley and Turner, 2005). Due to the clear identification of at least three bathymetrically differentiated habitats, three ESRI shapefiles (ESRI 2008) were imported for the different zones by using the $R$ package maptools 0.7-29 (Lewin-Koh and Bivand, 2009) and the collecting points were allocated a priori to the appropriate bathymetric zone. To mitigate the effects of unequal point distribution, the function smooth.ppp was applied with a Gaussian kernel weighting of a radius of $2 \mathrm{~km}$. Each of the 156 collecting points (see above) was attributed with the respective pairwise Bray-Curtis distances. Then, the dissimilarity at the spatial interval between two collecting points was estimated by a Gaussian smoothing factor.

\section{Results}

\subsection{Lithology and chronology of core Co1200}

Individual core segments of core Co1200 were correlated using XRF data, and lithological core descriptions, leading to a composite core of $2.63 \mathrm{~m}$ length. Based on sedimentological and geochemical data and lithological peculiarities three different lithofacies can be distinguished in the Co1200 sediment succession (Fig. 2). 


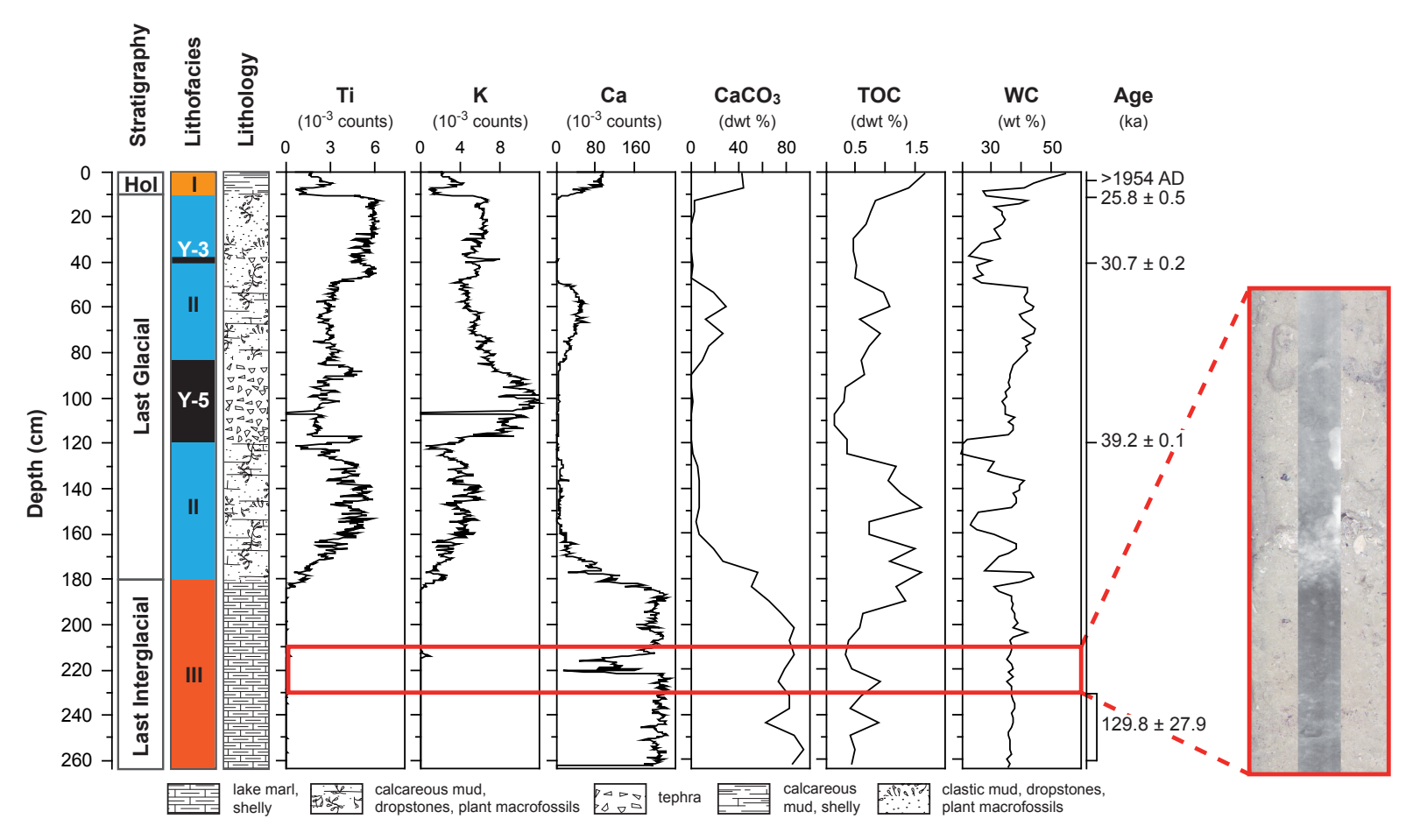

Fig. 2. Rough stratigraphic framework $\left(\mathrm{Hol}=\right.$ Holocene), lithofacies, lithology, Ti-, K-, Ca-intensities, $\mathrm{CaCO}_{3}$, total organic carbon $(\mathrm{TOC})$ dry weight percentages, water content (WC), and age control points of core Co1200. The red framed optical and radiographic images to the right show a horizon at $220 \mathrm{~cm}$ which consisted almost entirely of intact and broken mollusc fossils. Fossil mollusc specimens were solely extracted from the Lithofacies III sediment succession.

Lithofacies I between $0-13 \mathrm{~cm}$ is light-brown in colour and composed of massy calcareous $\left(\mathrm{CaCO}_{3}>40 \%\right)$ clayey silt and contains complete bivalve shells. TOC concentrations of up to $1.7 \%$ can be explained by finely dispersed organic matter $(\mathrm{OM})$ as well as small leaf and shaft fragments from Chara algae. Radiocarbon dating of plant macrofossils from Lithofacies I at $6 \mathrm{~cm}$ depth yielded a modern age ( $>1954$ AD) probably as a result of contamination with recent organic and plant material from bioturbation or from disturbance during coring of these soft and water saturated uppermost sediment section.

The transition from Lithofacies I to II is characterised by a $2 \mathrm{~cm}$ thick sand layer between 13 and $16 \mathrm{~cm}$ with an apparent erosive base. These findings in combination with hydroacoustic data from this site indicate a primarily erosive mass movement process (Lindhorst et al., 2010). Support for an erosional process and thus a hiatus in core Co1200 comes from radiocarbon dating just below the sand layer at $13 \mathrm{~cm}$, which yielded an age of $25.82 \pm 0.5 \mathrm{cal}$ kyrs BP.

Lithofacies II between 16 and $181.5 \mathrm{~cm}$ appears dark-grey and consists of massy clastic clayey-sandy silts with frequent occurrences of larger granules. Small shell fragments and larger intact Chara fragments are abundant. Except for the succession between c. $50-90 \mathrm{~cm} \mathrm{CaCO}_{3}$ and TOC concentrations are lower, whilst $\mathrm{Ti}$ and $\mathrm{K}$ intensities are significantly higher compared to Lithofacies I sediments. This is well correlated to higher amounts of clastic detritus. Two tephra horizons occur in Lithofacies II sediments at 38-40 (OT0700-1) and 85.5-120.5 (OT0700-2) cm. Geochemical and morphological investigation of glass shards from both tephra deposits allowed a correlation of the upper OT0700-1 tephra to the Y-3 tephra layer (Sulpizio et al., 2010), dated at $30.7 \pm 0.2 \mathrm{ka}$ (Sulpizio et al., 2003), and of the lower OT0700-2 to the Campanian Ignimbrite (CI)/Y-5 eruption of the Campi Flegrei Caldera (Sulpizio et al., 2010), dated to $39.2 \pm 0.1 \mathrm{ka}$ (De Vivo et al., 2001).

The transition from Lithofacies II to Lithofacies III sediments is abrupt and occurs within a few centimetres. These transitional centimetres contain gravel and sand with no observable grading, and reworked mollusc shells. Therefore it seems likely that the deposition of this transitional part occurred in a high energy erosive environment, which probably caused a hiatus in core Co1200 at the transition of Lithofacies II and III.

Lithofacies III sediments comprising the basal succession of core Co1200 between $181.5-263 \mathrm{~cm}$ appear massy, greyish-white, and consist almost entirely of silt-sized endogenic calcite $\left(\mathrm{CaCO}_{3}>70 \%\right)$ and intact and broken mollusc shells. Single horizons consisting almost entirely of mollusc shells and shell fragments are frequently interspersed in the fine grained calcite matrix. As indicated by extremely low Ti and $\mathrm{K}$ intensities, clastic matter is almost absent. Low TOC 
Table 1. List of mollusc taxa found in core Co1200. Semi-quantitative abundances of identifiable shell remains in the core, recent distribution, endemicity and abundance in Lake Ohrid are given. Fossil abundances: Less than 5 - rare, 5 to 50 - common, above frequent. For more details on recent occurrences of Gastropoda see Hauffe et al. (2010). Frequency of recent Bivalvia is according to Albrecht et al. (unpublished data).

\begin{tabular}{|c|c|c|c|}
\hline Taxon & Abundance in core & Recent distribution & Recent occurence in Lake Ohrid \\
\hline \multicolumn{4}{|l|}{ Gastropoda } \\
\hline Chilopyrgula sturanyi (Brusina, 1896) & frequent & Endemic to Ohrid Basin & frequent \\
\hline Ginaia munda (Sturany, 1894) & rare & Endemic to Lake Ohrid & frequent \\
\hline Ochridopyrgula macedonica (Brusina, 1896) & common & Endemic to Ohrid Basin & frequent \\
\hline Xestopyrgula dybowskii (Polinski, 1929) & rare & Endemic to Lake Ohrid & frequent \\
\hline Polinskiola sturanyi (Westerlund, 1902) & common & Endemic to Lake Ohrid & frequent \\
\hline Gyraulus lychnidicus Hesse, 1928 & common & Endemic to Lake Ohrid & frequent \\
\hline Planorbarius corneus (Linnaeus, 1758) & rare & Widespread & common \\
\hline Radix relicta Polinski, 1929 & common & Endemic to Ohrid Basin & frequent \\
\hline Valvata stenotrema Polinski, 1929 & frequent & Endemic to Ohrid Basin & frequent \\
\hline \multicolumn{4}{|l|}{ Bivalvia } \\
\hline Dreissena presbensis Kobelt, 1915 & frequent & North/Central Balkans & frequent \\
\hline Pisidium edlaueri Kuiper, 1960 & common & Endemic to Lake Ohrid & common \\
\hline Pisidium subtruncatum Malm, 1855 & rare & Widespread & rare \\
\hline Pisidium s. recalvum Kuiper, 1960 & rare & Endemic to Lake Ohrid & common \\
\hline
\end{tabular}

$(<1.2 \%)$ originates from finely dispersed OM and few leaf and shaft fragments of Chara algae. ESR dating of mollusc shells collected between $230-262 \mathrm{~cm}$ yielded a modeled age of $130 \pm 28 \mathrm{ka}$ (Lindhorst et al., 2010).

\subsection{Fossil mollusc composition}

A total of 13 mollusc species (9 gastropod species and 4 bivalve species; Fig. 3, Table 1) could be identified within Lithofacies III sediments. Generally, the calcified parts of the shells were well preserved, allowing in most cases for identification (Fig. 3). However, no remnants of organic shell components were found. The fossil fauna exclusively included species also found in the present fauna, i.e. no extinction events are obvious at the core site since the Last Interglacial. No morphological disparities between the shells of the fossil and recent assemblages could be observed either. No ambiguities of the fossil species compositions itself were shown, i.e. very similar recent assemblages exist.

The most abundant species in the core assemblage were Valvata stenotrema, Chilopyrgula sturanyi and Dreissena presbensis. The endemic pea-clam Pisidium edlaueri was common whereas two pea-clams, Pisidium subtruncatum and Pisidium subtruncatum recalvum, were rare. Among the rare gastropods were Planorbarius corneus, Xestopyrgula dybowskii, and Ginaia munda. Gyraulus lychnidicus, Radix relicta, Polinskiola sturanyi and Ochridopyrgula macedonica completed the assemblage as common members (Table 1).

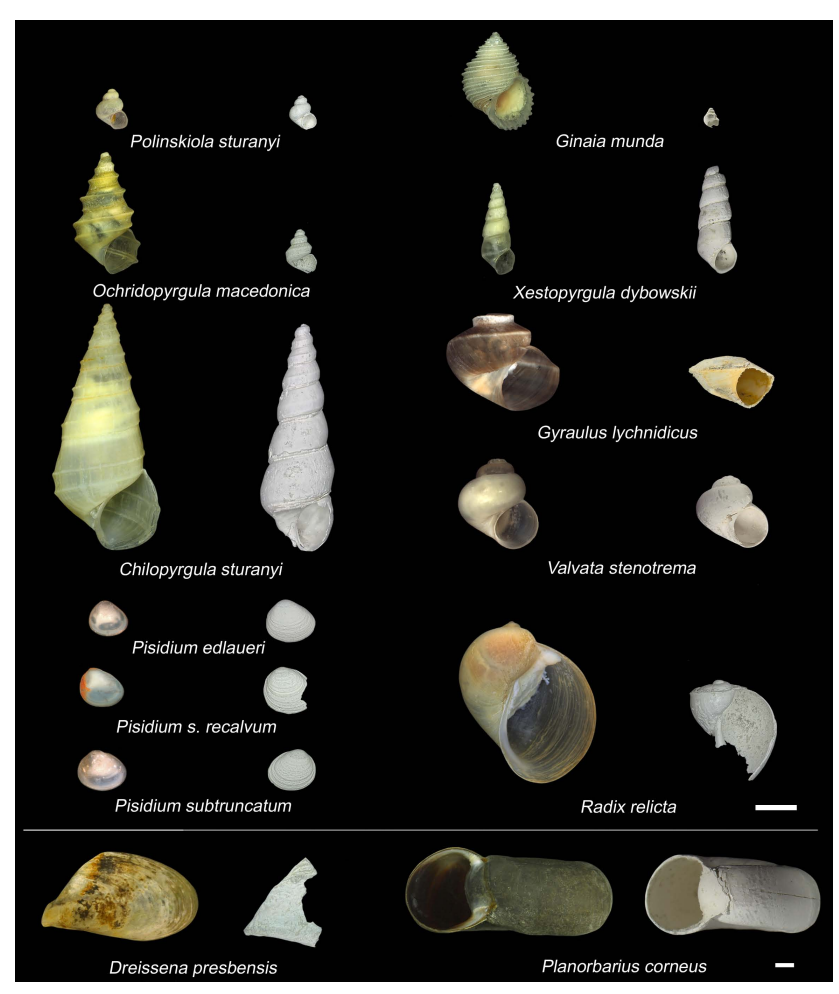

Fig. 3. Pairwise comparison of representative fossil mollusc specimens of core Co1200 (left specimens) and recent analoga from Lake Ohrid (right specimens). Scale bar is $2 \mathrm{~mm}$. 

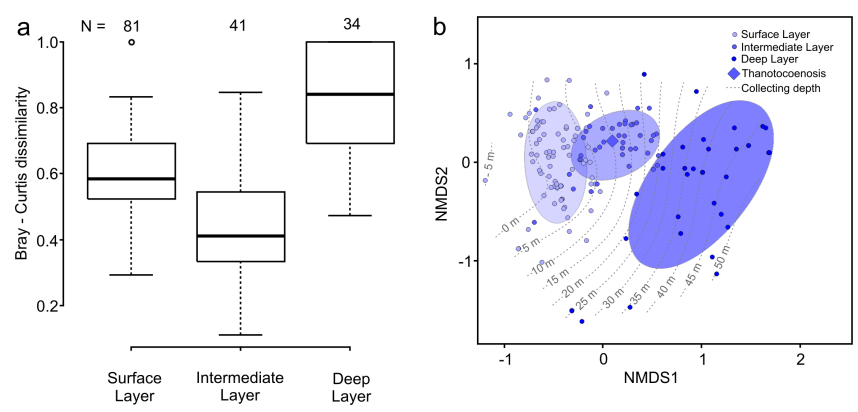

Fig. 4. (a) Quartile box plots of Bray-Curtis dissimilarities of the fossil and 156 recent gastropod assemblages. Assemblages from the Intermediate Layer habitats showed the significantly $\left(\mathrm{F}_{2,153}=\right.$ 52.44, $P<0.05$ ) lowest pairwise Bray-Curtis dissimilarity to the fossils of core Co1200. (b) Three-dimensional NMDS plot of gastropod communities (Stress value 15.4). According to vector fitting, the thanatoecoenosis is well nested within the ellipse with one standard deviation of the Intermediate Layer and the depth estimation equals $10 \mathrm{~m}$.

\subsection{Faunal similarity and depth range analysis}

To distinguish between the three potential habitats, pairwise Bray-Curtis dissimilarities were calculated between the fossil and 156 recent gastropod assemblages and classified into three potential habitat zones (Fig. 4a). The nonparametric anova (PERMANOVA) with Bonferroni adjustment $\left(\mathrm{F}_{2,153}=52.44, P<0.05\right)$ supported the significant differences between the three assignments. The Intermediate Layer showed the lowest Bray-Curtis distances to the fossil composition of core Co1200. The Surface Layer revealed a lower similarity and $50 \%$ of the Deep Layer dissimilarities did not overlap with $50 \%$ of the Intermediate Layer distances. The three-dimensional NMDS had a stress value of 15.4. According to vector fitting, the thanatoecoenosis is well nested within the ellipse with one standard deviation of the Intermediate Layer, and the depth estimation equals $10 \mathrm{~m}$ (Fig. 4b).

The $50 \%$ range of 11 of 12 species matches the depth range of the Intermediate Layer (Fig. 5), where recent collection points showed the highest similarity to the thanatocoenosis. The depth range of the Deep Layer was not covered by any of the occurring species, and the depth range of the Surface Layer by 6 of the 13 mollusc species.

The dissimilarity map (Fig. 6), which is based on pairwise Bray-Curtis distances between the fossil and the recent gastropod assemblages, had the lowest overall values for the Intermediate Layer (represented mainly by blue to green colours). The highest dissimilarity for this habitat zone was calculated for the sandy southern and north-eastern section. The Surface Layer is represented by green to yellow colours, with areas of higher dissimilarity at the south eastern shore. These dissimilarities are exceeded by the Deep Layer, predominantly appearing in orange to red colours. Drawing ar-

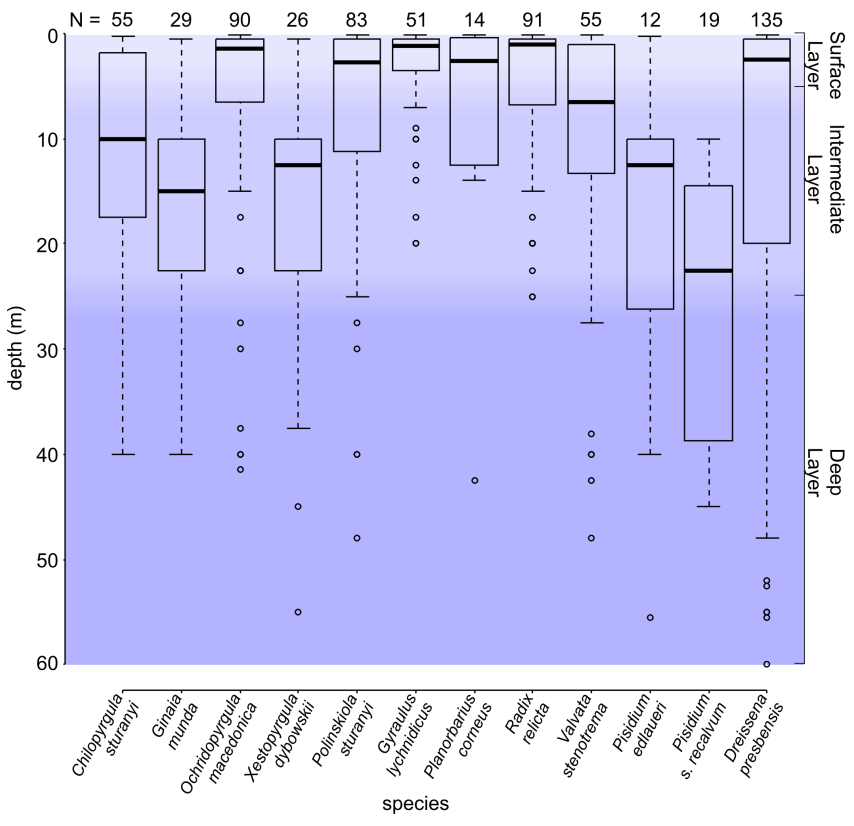

Fig. 5. Quartile box plots of observed depth ranges of recent members of the thanatocoenosis after balancing for unequal numbers of collection points. The $50 \%$ range of 11 of 12 species matches the depth range of the Intermediate Layer, where recent collecting points showed the highest similarity to the thanatocoenosis. The depth range of the Deep Layer was not covered by any of the species and the depth range of the Surface Layer by 6 of the 12 mollusc species.

bitrary transects perpendicular from the shore to the Deep Layer, the Intermediate Layer always reveals the lowest dissimilarity to the thanatocoenosis.

\section{Discussion}

\subsection{Record characteristics and palaeoenvironment}

Despite the large dating error of the ESR age of $130 \pm 28 \mathrm{ka}$ measured on bivalve and gastropod shells from Lithofacies III, we assume that deposition of calcareous sediments and mollusc fossils found therein took place under warm climate conditions during the Last Interglacial (probably MIS 5e). This assumption is supported by stratigraphic and paleoenvironmental constraints suggested by Lindhorst et al. (2010), and furthermore by investigations of sediment successions from pelagic sites at Lake Ohrid where carbonate sedimentation/preservation is restricted to interglacial periods (Vogel et al., 2010b). The peculiar sediment and geochemical characteristics in combination with the finding of intact mollusc shells in Lithofacies III and the fact that the sediments were recovered from a submerged terrace level at a water depth of $32 \mathrm{~m}$ point to deposition in a relatively low energy shallow 


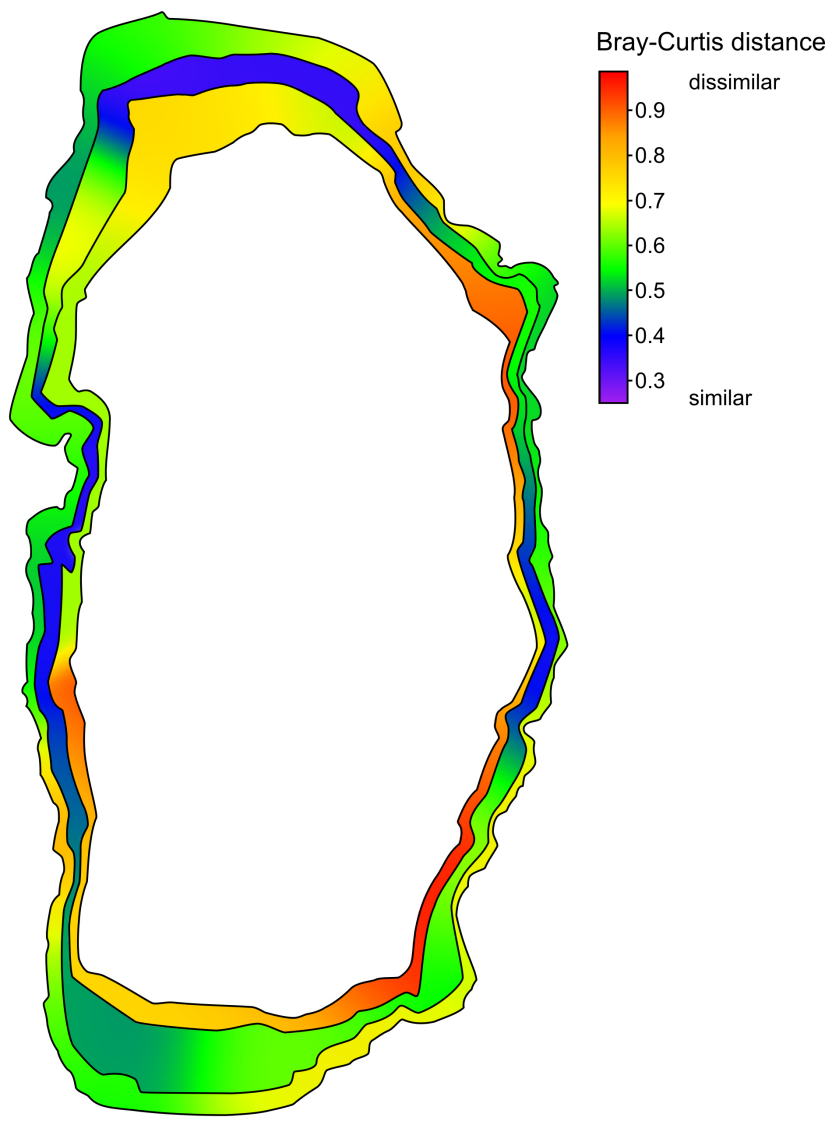

Fig. 6. Similarity map of the thanatocoenosis of core Co1200 and recent gastropod communities in ancient Lake Ohrid. Three habitat zones are shown: Surface Layer (0-5 m), Intermediate Layer (5$25 \mathrm{~m}$ ), and Deep Layer (25-50 m). Note that the extents of the zones are not to scale with Albrecht and Wilke (2008).

water environment of the Intermediate Layer (Lindhorst et al., 2010).

All species identified are assumed to still occur in Lake Ohrid. Therefore, a direct comparison of recent and fossil faunas is also possible within the context of bio-indication. The basic assumption of bio-indication is that niches and ecological requirements remain unchanged over the time frame of interest. As no changes in shell morphology could be observed, it can be assumed that no major shifts associated with adaptation to, for example, a specific niche have occurred. Such shifts, however, can occur rather rapidly in ancient lakes (Wilke et al., 2007).

The core Co1200 fauna is well nested in many of the 156 recent assemblages studied. Redeposition of mollusc shells by wave action or wind-induced currents from shallower sites or different parts of the lake cannot be completely ruled out. However, the excellent preservation of all shells recovered and the characteristics of the surrounding sediment facies imply that redeposition did not occur or that relatively short transport and rapid deposition in a calm environment took place. Thus, the overall depositional environment and sedi- mentary facies imply that taphonomic processes seem to be negligible.

\subsection{Comparison of recent and Last Interglacial fauna}

As noted in the introduction, the mollusc fauna of Lake Ohrid is extraordinarily endemic. The Co1200 fauna is likewise characterized by the dominance of endemic species with the exception of Planorbarius corneus and the bivalve species Dreissena presbensis and Pisidium subtruncatum (Albrecht et al., 2007, but see Wilke et al., 2010 for a discussion on the genetic peculiarities of Lake Ohrid D. presbensis). In this respect, i.e. dominance of endemics, the Last Interglacial fauna of Lake Ohrid does not generally differ from Neogene faunas of the Balkans (Harzhauser and Mandic, 2008).

The highest similarity in thanatocoenosis was found with recent species compositions occurring in the Intermediate Layer in depths between 5-25 m. The Intermediate Layer is the habitat zone with the highest overall gastropod diversity in Lake Ohrid (Hauffe et al., 2010). Thus the general habitat (depth) range indicated by the faunal composition fits well with the sediment characteristics of Lithofacies III and the stratigraphic and paleoenvironmental constraints outlined by Lindhorst et al. (2010).

None of the species recovered are characterized by particular adaptations to substrate or food, i.e. all species are rather opportunistic within the Ohrid fauna (see Hauffe et al., 2010). Judging from current habitat conditions and observations on where the recent species occur most often, a habitat with sandy-gravel substrate is most likely for the Co1200 fauna. This correlates accurately to the sediment features of Lithofacies III. Additional support for the suggested depth range $(5-25 \mathrm{~m})$ comes from leaf and shaft fragments of Chara remains in Lithofacies III. The absence of intact Chara algae specimens implies that deposition of Lithofacies III at site Co1200 did not take place within the Chara belt and that the mollusc community lived on open substrate rather than in the Chara belt itself.

\subsection{Faunal turnover and extinctions}

Whilst acknowledging that only a subset of the recent fauna was found in the thanatocoenosis, it is important to note that no particular faunal turnover has occurred since the Last Interglacial. Moreover, none of the species occurring in Eemian times became extinct. No changes in relative frequency were recognizable. This is somewhat remarkable, since faunal shifts and extinctions have been recognized for this major climatic change on the Balkans (Frogley and Preece, 2004). A possible explanation for the lack of major fauna change in Lake Ohrid is that this deep oligotrophic lake can buffer major environmental changes better than other lakes in the area (Leng et. al., 2010; Wagner et al., 2010; Wilke et al., 2010). 
Species extinctions are a major drawback in reconstructions of evolution and particular diversification rates. In the absence of a useful fossil record, it becomes extremely difficult and most often impossible to fully reconstruct evolutionary histories of recent taxa (Etienne and Apol, 2009). On the other hand, comparisons of fossil and recent faunas may lead to very interesting insights into factors generating biodiversity within a given hydrological setting. Such a study revealed the importance of major Pleistocene lake-level fluctuations on faunal evolution in Lake Malawi (Schultheiss et al., 2009). Lake Ohrid has the potential for similar studies now that fossil records are available. These records were not restricted to Lithofacies III of Co1200, but (less well preserved) shell material was present in Lithofacies II. Another core (Co1201) yielded mollusc material in Lithofacies II and IV, the latter dated to the penultimate glacial (Lindhorst et al., 2010). Recently, Holocene mollusc material has been recovered from cores drilled at the margins of Lake Ohrid (N. Hoffmann, personal communication, 2010).

\subsection{Potential of Lake Ohrid mollusc fossil record}

It has been shown recently that the sediments of Lake Ohrid are excellent archives for palaeoenvironmental reconstructions (Leng et al., 2010; Wagner et al., 2009, 2010; Vogel et al., 2010b; Reed et al., 2010). They cover the last glacial/interglacial cycle and yielded, for example, interesting insights into volcanic ash dispersal and climate change in the central northern Mediterranean region (Wagner et al., 2008a; Sulpizio et al., 2010; Vogel et al., 2010c). The new mollusc fossil record opens a valuable biological perspective for palaeolimnological and evolutionary reconstructions, particularly in respect to the role of environmental stability in generating biodiversity. In this context comparisons of fossil faunal assemblages and recent compositions can be enlightening. In Lake Pamvotis in Greece, for example, there are marked differences in the Plio-Pleistocene fossil compositions and the Holocene fauna. These differences were discussed in the context of lake-level and associated habitat changes (Frogley and Preece, 2004, 2007). Community changes did not only occur at the species level but major taxa shifts took place. This is obviously not the case for Lake Ohrid molluscs, at least not for the time frame since the Last Interglacial. The same holds true for the ostracode record (Belmecheri et al., 2009).

In the future, lake-level fluctuations and potential associated faunal changes in the Ohrid basin could be traced using additional sediment records from sites outside or inside the recent lake. The plains in the North and South of the present lake were flooded during phases of lake-level highstands (N. Hoffmann, personal communication, 2010) and may thus provide potential fossil mollusc records. The most promising information can be expected from foreset and terrace structures in the southern part of the basin dating back several $100 \mathrm{ka}$ (Lindhorst et al., 2010). These structures may provide potential fossil mollusc records for investigations of community changes, which may date back to the earliest stages of lake formation. The methodology outlined in this paper would also be applicable to such records.

Though many Neogene palaeolakes exist on the Balkan Peninsula (Harzhauser and Mandic, 2008), extant Lake Ohrid is among the few systems where both fossil and recent mollusc assemblages can be directly compared. Other such lakes include Lake Pamvotis and potentially Lake Dojran. Such comparisons may also help in recognizing recent faunal changes caused by increasing human impact and are thus important for establishing conservation strategies (Kostoski et al., 2010).

\section{Conclusions}

The first recovery of mollusc fossils from sediment cores in Lake Ohrid reported here opens a whole new perspective on evolutionary research in this famous ancient lake in particular, and to interdisciplinary research resulting from lake drilling in general. Given the well studied recent mollusc fauna, the approach outlined in this study might be applicable to future extended analyses using sediment records from already identified and significantly older foreset structures or terrace levels of Lake Ohrid. These records may shed more light on the impact of significant climatic and environmental change, on radiations, and causes for endemic biodiversity in this unique lake system. This system covers several Pleistocene glacial-interglacial cycles and perhaps even dates back to the Pliocene. Adding compatible data from Lake Prespa and former Lake Maliq would help to unravel the complex faunal evolution of the Dessarete Lake System. It can be hoped that a more longterm mollusc fossil record will be obtained during future deep drilling campaigns, enabling insight into the early evolutionary history of Lake Ohrid.

Acknowledgements. We are very grateful to the colleagues at the Hydrobiological Institute Ohrid for their tremendous support and joint projects. S. Trajanovski, B. Budzakoska, and S. Trajanovska provided valuable information and took part in some field trips. D. Georgiev generously supported our field work. We thank our students for their enthusiasm and help during field and laboratory work. U. Bößneck kindly helped with determinations of Pisidium spp. Z. Brdarovski has always been a trusty skipper and helped in many ways. We are grateful to B. Wagner and K. Birkhofer for fruitful discussions and F. Riedel, F. Wesselingh and an anonymous reviewer for their helpful comments on an earlier version of this paper.

This research was supported by DFG grants to CA (AL 1076/3-1), TW (WI 1902/8-1), and BW (WA2109/1-1).

Edited by: B. Wagner 


\section{References}

Albrecht, C., Hauffe, T., Schreiber, K., Trajanovski, S., and Wilke, T.: Mollusc biodiversity and endemism in the putative ancient lake Trichonis (Greece), Malacologia, 51, 357-375, 2009.

Albrecht, C., Schultheiß, R., Kevrekidis, T., Streit, B., and Wilke, T.: Invaders or endemics? Molecular phylogenetics, biogeography and systematics of Dreissena in the Balkans, Freshw. Biol., 52, 1525-1536, 2007.

Albrecht, C., Wolff, C., Glöer, P., and Wilke, T.: Concurrent evolution of ancient sister lakes and sister species: The freshwater gastropod genus Radix in lakes Ohrid and Prespa, Hydrobiologia, 615, 157-167, 2008.

Albrecht, C., Trajanovski, S., Kuhn, K., Streit, B., and Wilke, T.: Rapid evolution of an ancient lake species flock: freshwater limpets (Gastropoda: Ancylidae) in the Balkan lake Ohrid, Org. Divers. Evol., 6, 294-307, 2006.

Albrecht, C. and Wilke, T.: Lake Ohrid: biodiversity and evolution, Hydrobiologia, 615, 103-140, 2008.

Anderson, M. J.: A new method for non-parametric analysis of variance, Austral. Ecol., 26, 32-46, 2001.

Baddeley, A. and Turner, R.: Spatstat: an R package for analyzing spatial point patterns, J. Stat. Softw., 12, 1-42, 2005.

Banarescu, P. M.: Zoogeography of fresh waters, Vol. 2: Distribution and dispersal of freshwater animals in North America and Eurasia, Aula Verlag, Wiesbaden, 1991.

Belmecheri, S., Namiotko, T., Robert, C., von Grafenstein, U., and Danielopol, D. L.: Climate controlled ostracod preservation in Lake Ohrid (Albania, Macedonia), Palaeogeogr. Palaeoclimatol. Palaeoecol., 277, 236-245, 2009.

Croudace, I., Rindby, A., and Rothwell, G.: ITRAX: description and evaluation of a new multi-function X-ray core scanner, New techniques in sediment core Analysis, 267, edited by: Rothwell, G., Geological Society of London, London, UK, 51-63, 2006.

Danzeglocke, U., Jöris, O., and Weninger, B.: CalPal-2007 online: http://www.calpal-online.de/, last access: 21 July 2008, 2007.

De Vivo, B., Rolandi, G., Gans, P., Calvert, A., Bohrson, W., Spera, F., and Belkin, H.: New constraints on the pyroclastic eruptive history of the Campanian volcanic Plain (Italy), Mineral. Petrol., 73, 47-65, 2001.

Etienne, R. S. and Apol, M. E. F.: Estimating speciation and extinction rates from diversity data and the fossil record, Evolution, 63, 244-255, 2009.

Filippov, A. and Riedel, F.: The late Holocene mollusc fauna of the Aral Sea and its biogeographical and ecological interpretation, Limnologica, 39, 67-85, 2009.

Frogley, M. R. and Preece, R. C.: A faunistic review of the modern and fossil molluscan fauna from lake Pamvotis, Ioannina, an ancient lake in NW Greece: implications for endemism in the Balkans, in: Balkan biodiversity, Pattern and process in the European hotspot, edited by: Griffith, H. I., Kryštufek, B., and Reed, J. M., Kluwer Academic Publishers, Dordrecht, Boston, London, 243-260, 2004.

Frogley, M. R. and Preece, R. C.: A review of the aquatic Mollusca from Lake Pamvotis, Ioannina, an ancient lake in NW Greece, J. Conchol., 39, 271-295, 2007.

Goodwin, D. H., Schöne, B. R., and Dettman, D. L.: Resolution and fidelity of oxygen isotopes as paleotemperature proxies in bivalve mollusk shells: Models and observations, Palaios, 18, 110-125, 2003.
Harzhauser, M. and Mandic, O.: Neogene lake systems of Central and South-Eastern Europe: Faunal diversity, gradients and interrelations, Palaeogeogr. Palaeoclimatol. Palaeoecol., 260, 417434, 2008.

Harzhauser, M. and Mandic, O.: Neogene dreissenids in Central Europe: evolutionary shifts and diversity changes, in: The Zebra Mussel in Europe, edited by: van der Velde, G., Rajagopal, S., and bij de Vaate, A., Backhuys Publishers, Leiden/Margraf Publishers, Weikersheim, 11-29, 2010.

Harzhauser, M., Kern, A., Soliman, A., Minati, K., Piller, W. E., Danielopol, D., and Zuschin, M.: Centennial- to decadal-scale environmental shifts in and around Lake Pannon (Vienna Basin) related to a major Late Miocene lake-level rise, Palaeogeogr. Palaeoclimatol. Palaeoecol., 270, 102-115, 2008.

Hauffe, T., Albrecht, C., Schreiber, K., Birkhofer, K., Trajanovski, S., and Wilke, T.: Spatially explicit analyses of gastropod biodiversity in ancient Lake Ohrid, Biogeosciences Discuss., 7, 49534985, doi:10.5194/bgd-7-4953-2010, 2010.

Hauswald, A.-K., Albrecht, C., and Wilke, T.: Testing two contrasting evolutionary patterns in ancient lakes: species flock vs. species scatter in valvatid gastropods of Lake Ohrid, Hydrobiologia, 615, 169-179, 2008.

Kostoski, G., Albrecht, C., Trajanovski, S., and Wilke, T.: A freshwater biodiversity hotspot under pressure - assessing threats and identifying conservation needs for ancient Lake Ohrid, Biogeosciences Discuss., 7, 5347-5382, doi:10.5194/bgd-7-5347-2010, 2010.

Langlet, D., Alleman, L. Y., Plisnier, P.-D., Hughes, H., and André, L.: Manganese content records seasonal upwelling in Lake Tanganyika mussels, Biogeosciences, 4, 195-203, doi:10.5194/bg4-195-2007, 2007.

Leng, M. J., Baneschi, I., Zanchetta, G., Jex, C. N., Wagner, B., and Vogel, H.: Late Quaternary palaeoenvironmental reconstruction from Lakes Ohrid and Prespa (Macedonia/Albania border) using stable isotopes, Biogeosciences, 7, 3109-3122, doi:10.5194/bg7-3109-2010, 2010

Lewin-Koh, N. J. and Bivand, R.: maptools R package version 0729, available at: http://cran.r.project.org/, last access: 6 December 2009, 2009.

Lindhorst, K., Vogel, H., Krastel, S., Wagner, B., Hilgers, A., Zander, A., Schwenk, T., Wessels, M., and Daut, G.: Stratigraphic analysis of lake level fluctuations in Lake Ohrid: an integration of high resolution hydro-acoustic data and sediment cores, Biogeosciences Discuss., 7, 3651-3689, doi:10.5194/bgd-7-3651-2010, 2010.

Lirer, F., Harzhauser, M., Pelosi, N., Piller, W. E., Schmid, H. P., and Sprovieri, M.: Astronomically forced teleconnection between Paratethyan and Mediterranean sediments during the Middle and Late Miocene, Palaeogeogr. Palaeoclimatol. Palaeoecol., 275, 1-13, 2009.

Martens, K.: Speciation in ancient lakes (review), Trends Ecol. Evol., 12, 177-182, 1997.

Matzinger, A., Schmid, M., Veljanoska-Sarafiloska, E., Patceva, S., Guseska, D., Wagner, B., Müller, B., Sturm, M., and Wüest, A.: Eutrophication of ancient Lake Ohrid: Global warming amplifies detrimental effects of increased nutrient inputs, Limnol. Oceanogr., 52, 338-353, 2007.

Matzinger, A., Jordanoski, M., Veljanoska-Sarafiloska, E., Sturm, M., Müller, B., and Wüest, A.: Is Lake Prespa jeopardizing the 
ecosystem of ancient Lake Ohrid? Hydrobiologia, 553, 89-109, doi:10.1007/s10750-005-6427-9, 2006a.

Matzinger, A., Spirkovski, Z., Patceva, S., and Wüest, A.: Sensitivity of Ancient Lake Ohrid to Local Anthropogenic Impacts and Global Warming, J. Great Lakes Res., 32, 158-179, 2006 b.

Miller, B. B. and Thompson, T. A.: Molluscan faunal changes in the Cowles Bog area, Indiana Dunes National Lakeshore, following the low-water Lake Chippewe phase, in: Late Quaternary History of the Lake Michigan Basin, edited by: Schneider, A. F. and Fraser, G. S., Geol. Soc. Am. Special Paper, 251, 21-27, 1990.

Mischke, S., Rajabov, I., Mustaeva, N., Zhang, C., Herzschuh, U., Boomer, I., Brown, E. T., Andersen, N., Myrbo, A., Ito, E., and Schudack, M. E.: Modern hydrology and late Holocene history of Lake Karakul, eastern Pamirs (Tajikistan): A reconnaissance study, Palaeogeogr. Palaeoclimatol. Palaeoecol., 289, 1024, 2010.

Müller, J., Oberhänsli, H., Melles, M., Schwab, M., Rachold, V., and Hubberten, H.-W.: Late Pliocene sedimentation in Lake Baikal: implications for climatic and tectonic change in SE Siberia, Palaeogeogr. Palaeoclimatol. Palaeoecol., 174, 305-326, 2001.

Naumoski, T. B., Jordanoski, M., and Veljanoska-Sarafiloska, E.: Physical and Chemical characteristics of Lake Ohrid, in: $1^{\text {st }}$ International Symposium for protection of the natural lakes in Republic of Macedonia, Ohrid, Republic of Macedonia, 31 May 03 June 2007, 103-112, 2007.

Oksanen, J., Blanchet, F. G., Kindt, R., Legendre, P., O'Hara, R. G., Simpson, G. L., Solymos, P., Stevens, M. H. H., and Wagner, H.: vegan: Community Ecology Package. R package version 1.18-0/r1102, available at: http://R-Forge.R-project.org/ projects/vegan/, last access: 5 January 2010.

Reed, J. M., Cvetkoska, A., Levkov, Z., Vogel, H., and Wagner, B.: The last glacial-interglacial cycle in Lake Ohrid (Macedonia/Albania): testing diatom response to climate, Biogeosciences, 7, 3083-3094, doi:10.5194/bg-7-3083-2010, 2010.

Roelofs, A. K. and Kilham, P.: The diatom stratigraphy and paleoecology of Lake Ohrid, Yugoslavia, Palaeogeogr. Palaeoclimatol. Palaeoecol., 42, 225-245, 1983.

Rust, J.: Evolution, Systematik, Paläoökologie und stratigraphischer Nutzen neogener Süß- und Brackwassergastropoden im Nord-Ägäis-Raum, Palaeontographica, Abteilung A, 243, 37180,1997

Schellmann, G., Beerten, K., and Radtke, U.: Electron spin resonance (ESR) dating of Quaternary materials, Eiszeitalter und Gegenwart, Quat. Sci. J., 57, 95-149, 2008.

Scholz, C. A., Johnson, T. C., Cohen, A. S., King, J. W., Peck, J., Overpeck, J. T., Talbot, M. R., Brown, E. T., Kalindekafe, L., Amoako, P. Y. O., Lyons, R. P., Shanahan, T. M., Castaneda, L. S., Heil, C. W., Foman, S. L., McHargue, L. R., Beuning, K., Gomez, J., and Pierson, J.: East African megadroughts between 135-75 kyr ago and implications for early human history, Proc. Natl. Acad. Sci. U.S.A., 104, 16416-16421, 2007.

Schultheiss, R., Albrecht, C., Bößneck, U., and Wilke, T.: The neglected side of speciation in ancient lakes: phylogeography of an inconspicuous mollusk taxon in lakes Ohrid and Prespa, Hydrobiologia, 615, 141-156, 2008.

Schultheiß, R., Van Boxclaer, B., Wilke, T., and Albrecht, C.: Old fossils - young Species: the evolutionary history of an endemic gastropod assemblage in Lake Malawi, Proc. R. Soc. Lond., B,
Biol. Sci., 276, 2837-2846, 2009.

Schwarzer, J., Misof, B., Tautz, D., and Schliewen, U. K.: The root of the East African cichlid radiations, BMC Evol. Biol., 9, 186, 2009.

Sulpizio, R., Zanchetta, G., Paterne, M., and Siani, G.: A review of tephrostratigraphy in central and southern Italy during the last 65 ka, Il Quaternario, 16, 91-108, 2003.

Sulpizio, R., Zanchetta, G., D’Orazio, M., Vogel, H., and Wagner, B.: Tephrostratigraphy and tephrochronology of lakes Ohrid and Prespa, Balkans, Biogeosciences, 7, 3273-3288, doi:10.5194/bg-7-3273-2010, 2010.

Taylor, D. W.: Aspects of freshwater mollusc ecological biogeography, Palaeogeogr. Palaeoclimatol. Palaeoecol., 62, 511-576, 1988.

Tracey, S., Todd, J. A., and Erwin, D. H.: Mollusca: Gastropoda, The Fossil Record, 2, edited by: Benton, M. J., Chapman and Hall, London, 131-167, 1993.

Trajanovski, S., Albrecht, C., Schreiber, K., Schultheiß, R., Stadler, T., Benke, M., and Wilke, T.: Testing the spatial and temporal framework of speciation in an ancient lake species flock: the leech genus Dina (Hirudinea: Erpobdellidae) in Lake Ohrid, Biogeosciences, 7, 3387-3402, doi:10.5194/bg-7-3387-2010, 2010.

Van Bocxlaer, B., Van Damme, D., and Feibel, C. S.: Gradual versus punctuated equilibrium evolution in the Turkana Basin molluscs: Evolutionary events or Biological Invasions?, Evolution, 62, 511-520, 2008.

Van Damme, D. and Pickford, M.: The late Cenozoic Thiaridae (Mollusca, Gastropoda, Cerithioidea) of the Albertine Rift Valley (Uganda-Congo) and their bearing on the origin and evolution of the Tanganyikan thalassoid malacofauna, Hydrobiologia, 498, 183, 2003.

Vogel, H., Wessels, M., Albrecht, C., Stich, H.-B., and Wagner, B.: Spatial variability of recent sedimentation in Lake Ohrid (Albania/Macedonia), Biogeosciences, 7, 3333-3342, doi:10.5194/bg7-3333-2010, 2010.

Vogel, H., Wagner, B., Zanchetta, G., Sulpizio, R., and Rosén, P.: A paleoclimate record with tephrochronological age control for the last glacial-interglacial cycle from Lake Ohrid, Albania and Macedonia, J. Paleolimnol., 44, 2295-310, 2010 b.

Vogel, H., Zanchetta, G., Sulpizio, R., Wagner, B., and Nowaczyk, N.: A tephrostratigraphic record for the last glacial-interglacial cycle from Lake Ohrid, Albania and Macedonia, J. Quat. Sci., 25, 320-338, 2010c.

Wagner, B., Sulpizio, R., Zanchetta, G., Wulf, S., Wessels, M., and Daut, G.: The last 40 ka tephrostratigraphic record of Lake Ohrid, Albania and Macedonia: a very distal archive for ash dispersal from Italian volcanoes, J. Volcan. Geotherm. Res., 177, 71-80, 2008a.

Wagner, B., Reicherter, K., Daut, G., Wessels, M., Matzinger, A., Schwalb, A., Spirkovski, Z., and Sanxhaku, M.: The potential of Lake Ohrid for long-term palaeoenvironmental reconstructions, Palaeogeogr. Palaeoclimatol. Palaeoecol., 259, 341-356, 2008 b.

Wagner, B., Lotter, A. F., Nowaczyk, N., Reed, J. M., Schwalb, A., Sulpizio, R., Valsecchi, V., Wessels, M., and Zanchetta, G.: A 40,000-year record of environmental change from ancient Lake Ohrid (Albania and Macedonia), J. Paleolimnol., 41, 407-430, 2009.

Wagner, B., Vogel, H., Zanchetta, G., and Sulpizio, R.: Environmental change within the Balkan region during the past ca. $50 \mathrm{ka}$ 
recorded in the sediments from lakes Prespa and Ohrid, Biogeosciences, 7, 3187-3198, doi:10.5194/bg-7-3187-2010, 2010.

Watzin, M. C., Puka, V., and Naumoski, T. B.: Lake Ohrid and its watershed, state of the environment report, Lake Ohrid Conservation Project, Tirana, Republic of Albania and Ohrid, Republic of Macedonia, 2002.

Wesselingh, F. P.: Long-lived lake molluscs as island faunas: a bivalve perspective, in: Biogeography, time and place: distributions, barriers and islands, edited by: Renema, W., Springer, Dordrecht, 275-314, 2007.
Wilke, T., Albrecht, C., Anistratenko, V. V., Sahin, S. K., and Yildirim, Z.: Testing biogeographical hypotheses in space and time: faunal relationships of the putative ancient lake Egirdir in Asia Minor, J. Biogeogr., 34, 1807-1821, 2007.

Wilke, T., Schultheiß, R., Albrecht, C., Bornmann, N., Trajanovski, S., and Kevrekidis, T.: Native Dreissena freshwater mussels in the Balkans: in and out of ancient lakes, Biogeosciences, 7, 3051-3065, doi:10.5194/bg-7-3051-2010, 2010.

Williamson, P. G.: Palaeontological documentation of speciation in Cenozoic molluscs from the Turkana Basin, Nature, 293, 437443, 1981. 